\title{
EDITORIAL
}

\section{Aboagora 2013: The Human Machine}

n 2011, Aboagora, the innovative and experimental symposium, was arranged for the first time in Turku/ Åbo, Finland; scheduled to coincide with Turku Music Festival, an event that has drawn music lovers to the city for more than half a century, artists and academics met to exchange ideas and to discuss and challenge the boundaries as well as the connections which lie between their different fields of work and expression. Two years later, Aboagora was arranged for the third time, and it has developed into a widely recognised and valued concept which constantly seeks to introduce new trajectories of thought into the dialogue between the arts and sciences. This issue of Approaching Religion gathers some of the talks and panel discussions presented at Aboagora 2013. In previous years, Aboagora has tackled topical themes such as 'Rethinking Enlightenment' (2011) and 'The Power of the Sacred and the Secular' (2012). This year, focus was directed towards the encounter of human bodies and minds with contemporary technology, under the heading 'The Human Machine'.

The Relationship BETWEen MAN AND MACHINE is complex to say the least. As noted on the Aboagora website, human beings can themselves be viewed as corporeal machines: assemblages of forces, actions and mechanisms. Furthermore, the machine can be seen as an extension of the human senses. The boundaries between man and machine can be blurred by the use of technological devices as integral parts of the human body. In this context, it is not implausible to ascribe human qualities to machines; to assume that machines may feel and think and acquire personal qualities of a kind that are generally associated with fellow beings or pet animals. Machines can be viewed in a positive light, as vehicles of human creativity and as tools for expressing abstract thoughts. Nevertheless, one can also take a more negative view of technology, regarding it as a violator of genuine human interaction which distances human beings from one another and robs them of both agency and integrity. In recent decades such considerations have provided fertile ground for artistic and scientific explorations, a discussion that Aboagora sought to join this year.

In the first article, Professor Kevin Warwick presents current implant technology, especially the issue of linking human brains with computers, of which he has direct personal experience. He describes how culturing biological neurons and placing them in a robot body (forming robots with biological brains) can open up new avenues of possibility - and peril for contemporary medicine and technology, as well

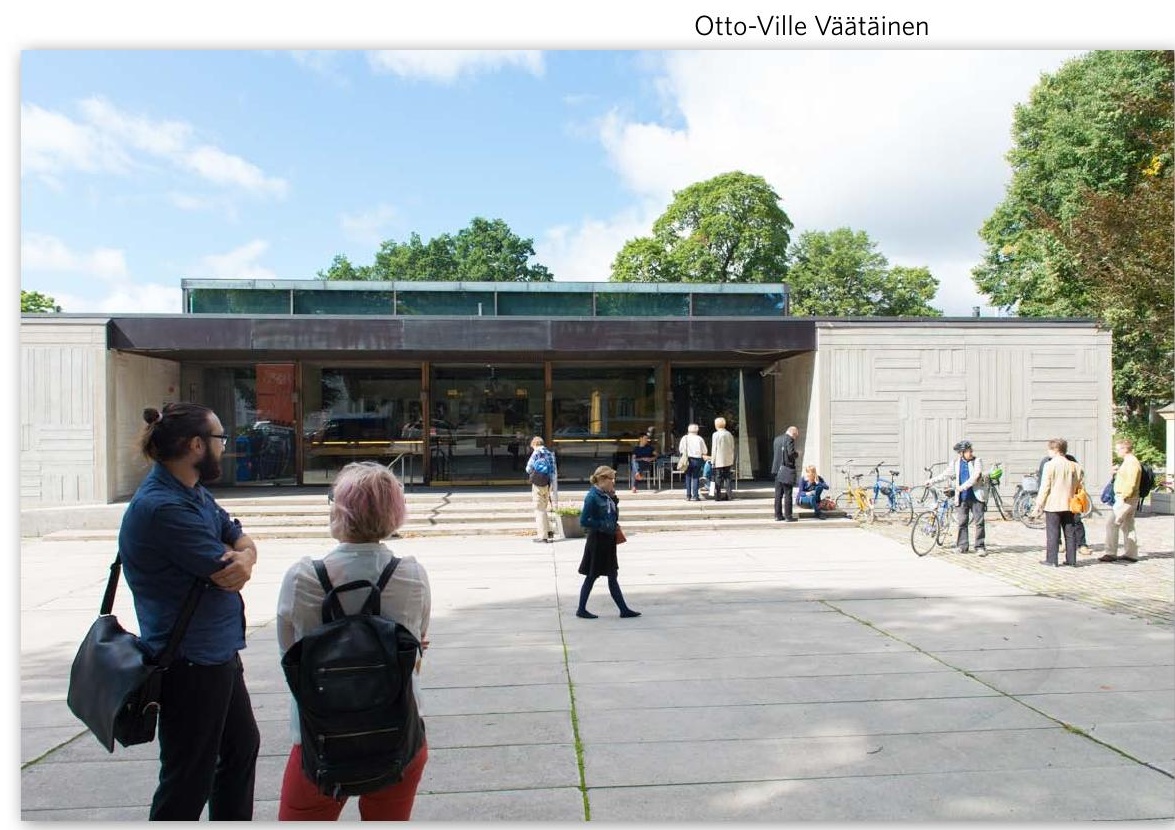

The third Aboagora gathered participants from many fields in art and academia to the Sibelius Museum in Turku/Åbo in August, 2013. 
as how such developments make it increasingly difficult for us to tell the difference between human beings and machines as we encounter them in various contexts. As a conclusion, this first real-life cyborg (as Professor Warwick famously describes himself) takes a brief look at the future and where the development in his opinion is heading. The second article presents another kind of meeting between human beings and technology. Here, the researchers Veera Mustonen and Mika Pantzar from the National Consumer Research Centre (Finland) present a large-scale, explorative study in which refined technology was used to track the daily rhythms of stress and recovery among a number of research subjects. This quantitative data of heart rates and algorithms was also connected to qualitative descriptions gathered through interviews and personal inputs. The heart and the mind do not always speak the same language when describing the stresses and anxieties of daily life, Mustonen and Pantzar conclude: the human experience has depths that the machine cannot plumb.

The telephone is used as an example of technology as both a tool and a trap for human communication in the third article of this issue. For the panel discussion 'Media Machines' Professor John Armitage presented the idea that the mobile phone is not only a vehicle of human freedom of expression, but increasingly also a means for electronic eavesdropping. Thus, he argues, media technologies can be both liberating and imprisoning at the same time. The article on social media that follows presents discussions within a panel focusing on the implications of social media for everyday life, politics and human agency. The authors - Professors Mia Lövheim and Susanna Paasonen together with the researchers André Jansson and Johanna Sumiala, all scholars of media and social sciences - underline that the digitalization of everyday life illustrates how issues of identity, agency and power cannot be attributed to the individual or the machine alone. Rather, attention should be paid to the interactions and negotiations within a network of actors, where humans and machines meet.

Finally, Tamara Milosevic and Alice Della Penna present the outcome of an interdisciplinary student workshop that met under the auspices of Aboagora. During the course of a few intensive and innovative days in the archipelago, students of various academic backgrounds took part in this training opportunity which aimed at developing what the facilitators denote 'essential twenty-first century skills': to introduce and develop creative, critical and interdisciplinary thinking, collaborative teamwork, as well as visual and scientific literacy, using project-based learning and hands-on activities. The outcome is a visionary plan for improving the ecological condition of the Baltic Sea, a 'Mosaic of Life.' The issue ends with some concluding reflections by the current coordinator of Aboagora, MA Anna Haapalainen. Having summed up the implications of the past Aboagora, Haapalainen turns her gaze to the future, introducing the theme of Aboagora 2014: Chaos and Cosmos.

Blessing or curse, utopia or dystopia? The conglomerate of ideas developing around the Human Machine can be assessed in diametrically opposing ways, depending on the specific context in which the issue is raised, as well as the values, prospects and interpretations of the person posing the question. Thus, Aboagora has once more resulted in a meeting of art and science that provides food for thought rather than straight and self-assured answers.

\section{RUTH ILLMAN Editor of Approaching Religion}

Dr Ruth IIIman is Director of the Donner Institute for Research in Religious and Cultural History, associated to Åbo Akademi University in Åbo, Finland. She is committed to research on interreligious dialogue and the role of the arts in this dialogue, cultural encounters and peace research. She is also the editor-in-chief of the international peer-reviewed journal Temenos: Nordic Journal of Comparative Religion. Illman has published widely in international journals such as the International Journal of Public Theology, the Journal of Contemporary Religion, and Studies in Interreligious Dialogue. Her recent books include Art and Belief: Artists Engaged in Interreligious Dialogue (Equinox Publications, 2012) and together with Prof. W. Alan Smith Theology and the Arts: Engaging Faith (Routledge, 2013). Email: rillman(at)abo.fi; website: <www.abo.fi/donnerinstitute>.

\section{Links}

Aboagora website: <www.aboagora.fi>.

Interviews and articles about Aboagora 2013 (in Swedish), Meddelande från Åbo Akademi: <http://mfaa.abo.fi/ wp-content/uploads/2013/o9/mfaa_11_132.pdf>. 